\title{
Human Rights and Social Justice in Social Work Education: A Critical Realist Comparative Study of England and Spain
}

\author{
The history of social work as a profession and academic discipline is inextricably \\ linked with principles of human rights (HR) and social justice (SJ). The Global \\ Standards for social work education promote HR and SJ as unifying themes, yet there \\ is little understanding of how these themes are embedded in social work education in \\ specific national contexts. This article, based on empirical research in England and \\ Spain, explores social work educators' understandings of, and strategies used in \\ learning and teaching about, HR and SJ. Using a critical realist framework, a web \\ survey was followed by qualitative interviews with educators in each country to \\ identify opportunities and challenges in stimulating students' theoretical understanding \\ of HR and SJ, and their application in practice. Findings show that prevailing \\ neoliberal ideology has pervaded social work in both countries (more strongly in \\ England) placing pressure on social work educators to convey narrow understandings \\ of HR and SJ and to adopt increasingly bureaucratic and distant relationships with \\ students. Identifying a range of factors informing educators' understandings of HR and \\ SJ, the research identifies spaces for strengthening the focus on HR and SJ in social \\ work education. The article argues that while university-based social work education \\ remains a fertile site for the deconstruction of neoliberal ideology that threatens the HR \\ and SJ foundations of social work globally, social work and social work education \\ require the development of a distinct, alternative, HR and SJ-based ideology.
}

Keywords: human rights, social justice, critical realism, neoliberalism, social work education, England, Spain.

Acknowledgements: This research was supported by the UK Economic and Social Research Council. We thank two anonymous reviewers for their comments on an earlier version of the article. 


\section{Introduction}

Across the world people are suffering the effects of increasing inequality, the consequence of aggressive neoliberal globalization and the rapid spread of systems and mechanisms to support and maintain its dominance. Even in countries with welfare traditions, such as England and Spain, the vast majority are experiencing reductions in their standard of living with increasing numbers experiencing poverty or extreme poverty. Human rights are being violated through the degradation of working conditions, the retreat of civil liberties on grounds of national security, austerity measures, and the degradation of natural environments (Dominelli, 2012; Lundy, 2012).

Neoliberalism, as a political-economy theory, claims that the most effective and desirable way of promoting human wellbeing is removing social and political constraints to free market mechanisms, allowing their optimum operation to deliver maximum economic growth (Harvey, 2005). But these theoretical ideas are inconsistent with overwhelming evidence of increases in poverty and inequality during periods of neoliberal policy globally (Piketty, 2014), in Europe (De Vogli, 2013), and specifically in England and Spain (FOESSA, 2013; The Equality Trust, 2017).

Concepts of human rights (HR) and social justice (SJ) underpin the social work profession internationally (IFSW and IASSW, 2014) and are reflected in codes of ethics worldwide (Banks, 2006), including those of the British and Spanish national associations of social workers (BASW, 2014; CGTS, 2012). In an increasingly complex and globalized world, social problems gain an international dimension as structural inequalities are deepened by uncontrolled neoliberal market mechanisms, and the HR and SJ framework of social work gain increasing importance in countering narrow, market driven, approaches to address the needs of service users (Dominelli and Khan, 2000). 
As neoliberal ideology challenges the nature of social work and social work education Lavalette (2011) has described social work as being at a crossroads. In one direction lies the reinvention and strengthening of the critical tradition towards the achievement of social justice. In the other lies the defeat of the critical tradition and further marginalisation of the profession as a force against the pernicious effects of neoliberalism in undermining HR and SJ. Higgins (2015) has recently highlighted the confrontation between 'a broad conception of social work as understood by the International Federation of Social Workers' (IFSW) and the bureaucratic approach to social work in England, aligned with a neoliberal education model focussing 'on the service user as the "problem" and disengaged from the wider socio-political context of contemporary society’ (Higgins, 2015, p.12). This confrontation, he argues, represents a struggle for the soul of social work and presents particular dilemmas for social work educators. Human rights and social justice are central social work values, yet educators find themselves working within education systems increasingly influenced by neoliberal ideals. For social workers to feel empowered to embed HR and SJ in their practice, it is fundamental that schools of social work make HR and SJ central to social work education (Dominelli, 2004; Sewpaul and Jones, 2005).

This article draws on a doctoral study of social work education in England and Spain, addressing the following research questions: i) what are social work educators' understandings of HR and SJ in social work education in England and Spain? ii) what learning and teaching strategies are used to transmit HR and SJ to social work students? and iii) what can be learned from educational practices in the two countries to help social work educators maintain and strengthen social work's core values of HR and SJ?

The study was set against the European socioeconomic crisis associated with unbridled capitalist mechanisms and the irresponsible behaviour of financial institutions, economic and political powers (Jordan and Drakeford, 2012; Lundy, 2011). Used to justify 
the imposition of austerity agendas in Europe, the crisis visibly increased suffering amongst the most vulnerable (Eurostat, 2013) presenting social workers with ever increasing challenges in fulfilling their professional roles.

The comparative focus of the study is informed by the experience of the lead author who qualified and practised as a social worker in Spain before embarking on postgraduate study in England. Despite the commitment to HR and SJ embodied in the international definition of social work and codes of social work ethics in both countries, experience of the Spanish and English contexts suggested rather different understandings and applications of these values in social work education and practice. These differences offered fertile ground to compare the responses of social work education in these culturally contrasting European countries to the impact of neoliberalism on the profession and its service users, and to identify opportunities to reclaim more emancipatory forms of social work.

Following an outline of the study's theoretical underpinnings, research design and methods, two findings sections focus respectively on i) educators' understandings of HR and SJ and ii) strategies used in learning and teaching about HR and SJ. Drawing on the tenets of critical realism (Bhaskar, 1979), and critical discourse analysis (Fairclough, 2010), we discuss these findings in more detail, focussing on the oppressive ideology of neoliberalism and the factors that mediate responses to neoliberalism. Using Fairclough's notion of a 'positive critique' (2010, p. 2), we argue for the development of an alternative ideology of HR and SJ-based social work (IFSW and IASSW, 2014) to counter the prevailing pressures of neoliberalism.

\section{Theoretical underpinnings, study design and methods}

Comparing social work education in the two countries required a balance between breadth and depth of understanding, leading to the adoption of a mixed methods approach 
within a critical realist framework (McEvoy and Richards, 2006), offering the potential for the study to 'prise open the black box' to identify opportunities to reclaim more emancipatory forms of social work (Houston, 2010). Critical realism assumes the existence of an external social reality that is not directly observable; a complex reality where social phenomena are the result of a series of generative mechanisms (Bhaskar, 1989), interacting with each other in particular contexts. From a critical perspective, theory, values and politics are inseparable from research evidence, forming 'critical contextual features' of the research process, ‘intertwined with knowledge claims’ (Soydan, 2010, p.131).

Data were collected through a web-based survey of social work educators distributed to all educational institutions offering undergraduate social work qualifying courses in England (N=83) and Spain (N=39). These were followed by in depth interviews with a small sample $(\mathrm{N}=7)$ of social work educators from one university in each country, selected purposively for its overt commitment to HR and SJ-based social work education demonstrated through published mission statements and programme information. Acknowledging the low response rates associated with web-based surveys and challenges in generalising from interviews based on a small purposive sample as limitations of this study, these sampling strategies and methods of data collection supported the broader goals of the research in combining breadth with depth of information to identify strategies of resistance to the spread of neoliberal ideology in social work education.

The web survey, achieving responses from 41 educators in 23 English institutions and 35 educators from 13 Spanish institutions, generated qualitative information through open ended questions about educators' understandings of, attitudes and personal commitment to, HR and SJ, as well as their strategies for learning and teaching about HR and SJ. The interviews explored these questions in greater depth. Assisted by Nvivo software (Bryman, 2016), interview transcripts and responses to open ended questions from the survey were 
analysed thematically and subject to elements of critical discourse analysis (Fairclough, 2003). This involved multiple readings of the data with the explicit purpose of identifying underlying discourses described by Fairclough (2003: 123) as 'ways of representing' aspects of the social world which are enacted in, but have greater permanence than, particular texts or speeches, being linked with deeper ideologies and social structures. A coding structure was created to bring together different expressions of the same discourse. For example, various references to the function of contemporary mainstream social work in England as a mechanism of oppressive neoliberalism were coded 'mainstream social work in England: oppressive' and considered as a single discourse.

In addressing each research question, combinations of relevant empirical research findings were interpreted in line with the principles of critical realism (Bhaskar, 1979) through a process of retroduction. This involved going back from, below, or behind, observed regularities (Blaikie and Priest, 2017) to identify the historico-political, cultural and socioeconomic factors shaping understandings of HR and SJ. Involving successive cycles of deduction and induction, linking theory with empirical data, retroduction allows for differing interpretations to be drawn together to suggest causal tendencies, mechanisms that operate in subtle ways, to explain events and suggest ways of responding to them (Danermark et al., 2002; Houston, 2010). Pursuing the example of a single discourse: 'mainstream social work in England: oppressive', the process of retroduction revealed explicit links with the ideology of radical social work in England and with wider theoretical argument about the impact of neoliberalism on the social work profession in England. This prompted further reflection, as part of the process of retroductive thinking, about the absence of a similar discourse in data generated from social work educators in Spain. Among the possible explanations or 'potentially operating causal mechanisms' (Houston, 2010), those considered to have greater explanatory power, such as the different historical links between social work and welfare 
systems in each country, were explored further to offer carefully informed interpretations of the research findings. We make no claims to singular truths here. Rather we adhere to Blaikie and Priest's (2017) articulation of the process of retroduction as requiring creativity as well as deep familiarity with the contexts of the research, and relevant theory, to inform the development of emerging argument. In the following section we present the results of this process in identifying social work educators' understandings of HR and SJ.

\section{Social work educators' understandings of human rights and social justice.}

Social work educators in England largely understood HR and SJ as separate concepts and areas of knowledge. For example:

In my opinion, they're not that similar. Social justice is more amenable to widely differing policy interpretations than human rights, and social justice doesn't have an explicit legal or treaty structure in UK law (survey 39)

Many of the questions talk about 'human rights and social justice' as though these terms are inevitably lined or inextricably woven together. In fact, it is entirely possible to discuss human rights in terms of individuals' rights without any linkage to social justice (survey 30)

The notion of rights tends to individualise and I think that, although that's important there are limits to that. And I think that a collective orientation underpins notions of social justice (interview 2)

As these examples indicate, human rights were understood in legal terms, focussing on first generation civil and political rights enshrined in the UK Human Rights Act 1998. The relevance of human rights for social workers' roles was understood in terms of compliance with statutory human rights and legal responsibilities towards individual service users. This narrow approach represents a technical rather than a professional approach, leaving social 
work practice highly susceptible to party political interests illustrated starkly by the Conservative Government's recent attempts to repeal the Human Rights Act (Murray, 2017). The British Association of Social Workers reflects similar concerns in its Human Rights Policy that recognises and seeks to address the fact that:

\footnotetext{
"Human rights" as they have been passed into legislation in the UK have often been given a narrower meaning than the understanding social workers have as a profession... (BASW, 2015, p.4)
}

In contrast to these narrow understandings of $\mathrm{HR}$ and the separate consideration given to HR and SJ found in England, social work educators in Spain understood the two concepts as being intrinsically linked, including individual and collective rights. One educator explained:

I understand that social work is closely linked with the struggle for justice, and the struggle for justice is a struggle for human rights (interview 4).

Another explained that HR and SJ were 'closely interlinked' in teaching, 'revolving around one another' (interview 3, Spain).

For educators interviewed in Spain, the social work profession had an important and unquestionable responsibility to defend HR and promote SJ. Human rights responsibilities were seen as being shared by government, civil society and professions with social work having a particular responsibility in line with the global definition of social work. Educators were fully aware of, and engaged with, structural, activist, preventive and developmental dimensions of SJ. This was of particular relevance as the impact of extreme austerity measures being imposed across Spain were seen as clear examples of social injustice and violations of HR. For instance, one educator referred to the relationship between HR and SJ in social work as 'extremely close' and described the triple alliance of HR, SJ and social 
work as 'highly powerful' (interview 1). She linked her views directly to the international definition of social work:

The IFSW's ... new definition even assimilates HR and SJ as the motivation and justification of social work. Therefore, from the very roots of our profession it is clearly being made explicit the fact that social work has as a pillar, as a foundation, and thus as a channel always to travel together with the defence of human rights and to establish norms and possible mechanisms for achieving social justice.

The social work educators interviewed in England expressed strong engagement with HR and even stronger engagement with SJ, arguing the need to promote these values within the social work profession. However, their understandings of the alliance of HR and SJ in social work were closely linked with their personal and/or political values and their concerns about current and future directions in social work and social work education. One explained:

... from the age of about 12 I have been interested in issues of social justice and being politically oriented if you like ... And the reason I was drawn towards working in social care was because I felt it was one way of realising the notion of social justice (interview 2)

And another:

The people that social workers work with ... get a hard time from society... they deserve one group of professionals that will stand up and speak out for them and be alongside them, and that's my vision of what the social worker should be... We emphasise it throughout the course, whenever we can we talk to them about the social causes of private pain .... the political nature of social workers' tasks. (interview 3 )

Just as social work educators in Spain, those in England were concerned about the direct effects of neoliberal politics and mechanisms on the most vulnerable groups of people in society. But they also highlighted the further oppression of vulnerable groups by a welfare system and social work profession being reshaped along neoliberal lines. 
What is happening with social work ... is that it's now a system for fixing people to fit the system ... We teach students to think about human rights and social justice, [but] I wonder if that's all undone when it comes to practice (interview 1).

Oppressive practice settings and the tension between students' focus on employability and social work principles were noted in survey responses as challenges for social work educators in England. For example:

The jobs we are training students to fill now may have the label social work but in reality they are administrative agents of statutory services and if we encourage them to focus on rights and justice they will not survive that long (survey 9)

These practice-based challenges did not feature in the responses of social work educators in Spain raising the interesting question of what might account for the differences.

The research findings suggested that while HR and principles of SJ were central to social work education in Spain, in England their place in social work education was highly contested. Using the process of retroduction (Blaikie and Priest, 2017) described earlier, ideological, historico-political, cultural and socio-economic factors were identified as influential in shaping different understandings of HR and SJ in social work education in England and Spain and, we argue, underpin educators' strategies for facilitating learning and teaching about HR and SJ. A model of these causal mechanisms is shown in Figure 1.

Figure 1: Model of causal mechanisms informing social work educators' understandings of: $\mathrm{HR}$ and SJ and subsequent strategies for learning and teaching 


\section{Causal mechanisms}

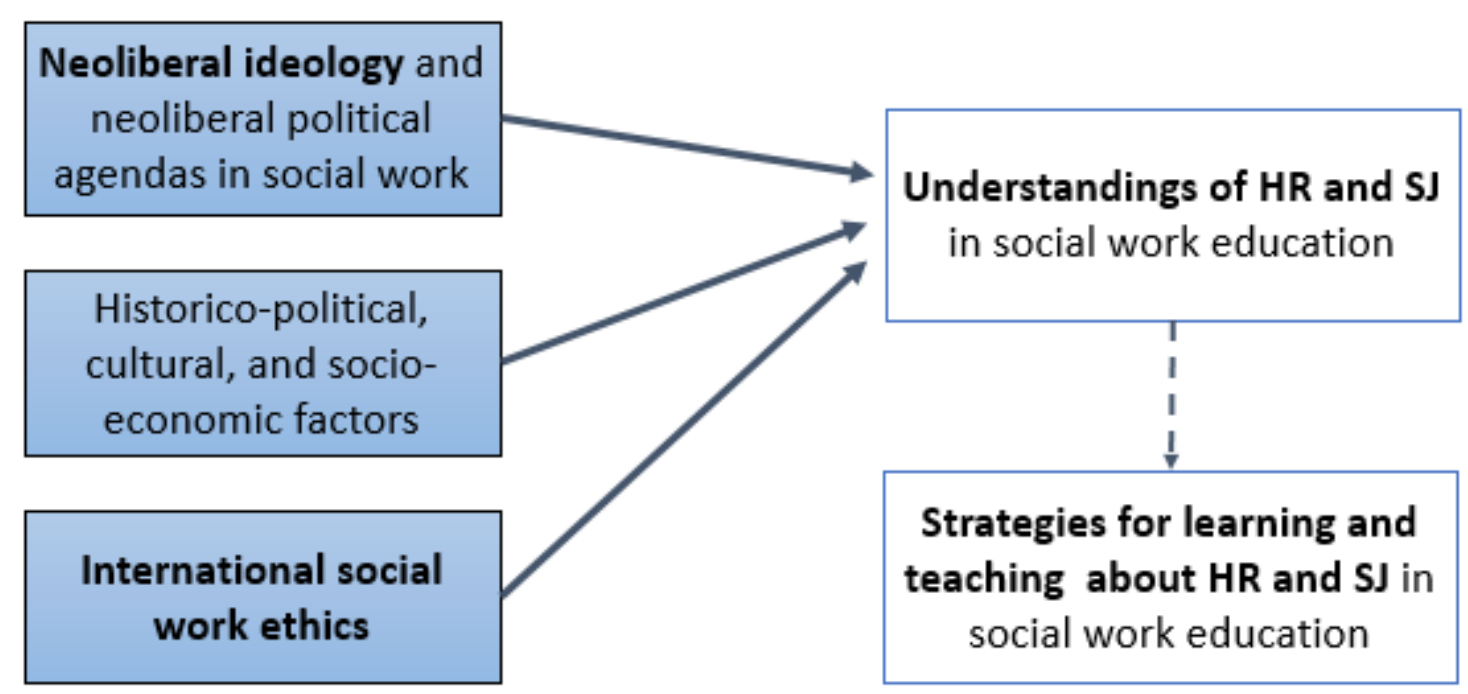

\section{Strategies for learning and teaching about human rights and social justice.}

In both countries tension was evident between the ethical commitment of the social work profession to HR and SJ, and neoliberal ideology that was driving narrow models of social work education, undermining the value-base of the profession. Ideology, defined as a 'systematic body of ideas' (Hall, 1977, p.4) including collective beliefs, values and interests (Carey and Foster, 2011) is conceptualised in critical theory as a means of maintaining power and domination (Fairclough, 2010) setting a basis for assessing whether the use of specific discourses leads to social wrongs that require mitigation to avoid threatening human wellbeing. Fairclough (2010) argues that critical theory can also be used to develop 'a positive critique' to identify and analyse ways in which oppressive ideology can be resisted.

Exploring strategies used by educators to develop students' critical understandings of HR and SJ, of the pernicious effects of, and strategies to resist, neoliberalism, revealed a range of practices. These included strengthening the focus of learning and teaching about histories and theories of HR and SJ; stressing the importance of structural theory to 
complement theoretical understanding of social work with individuals; connecting knowledge and theoretical understanding with contemporary social work practices; and creating safe discussion spaces for the exploration of experiences and understandings of injustice. Educators' own commitment to values of HR and SJ, supporting collective action by students, raising awareness of international developments in social work, and identifying opportunities for international networking and periods of practice in international settings, were also considered effective in enabling students to develop more critical understandings of HR and SJ.

Despite these strategies for promoting greater engagement with HR and SJ, findings from the survey pointed to the predominance of a narrow neoliberal conceptualisation of social work and social work education in England posing one of the main constraints to incorporating meaningful learning and teaching about HR and SJ in the social work curriculum. Educators in Spain identified fewer challenges for teaching in these areas, referring to curriculum content and practical methods for facilitating links between theory and practice. Interview participants in both countries were openly critical of neoliberal ideology, its effects on society and the social work profession. Unsurprisingly, given their recruitment from universities and courses known for their commitment to HR and SJ, they were keen to explain how they attempted to convey through their teaching, models of social work that embody human rights and values of social justice. In both countries educators' views embodied anti-capitalist ideology, for example 'market needs are prioritised over people's needs' (England), and 'people are exploited and dehumanised' (Spain). Interview participants in both countries drew on discourses of radical social work referring to 'the public causes of private pain', and the role of social work in 'fixing people to fit a capitalist system'. It was notable, however, that educators in Spain drew heavily on ethical discourses 
of international social work, focussing more closely on citizenship rights and welfare state ideology.

In terms of critical realism the ideologies of neoliberalism and international social work ethics, mediated by historico-political, cultural and socio-economic influences, were inextricably linked with social work educators' understandings of HR and SJ which in turn informed strategies for learning and teaching about $\mathrm{HR}$ and $\mathrm{SJ}$ as illustrated in Figure 1. In the following section we discuss neoliberalism, conceptualised as an oppressive ideology, in more detail before expanding on the factors mediating responses to the threats posed to social work education and practice by neoliberalism.

\section{The oppressive ideology of neoliberalism in social work}

Numerous authors have described how government led marketization processes have reshaped social work, diminishing its autonomy, professional scope and standards (Bamford, 2015; Dominelli, 2004, 2010; Dustin, 2007; Ferguson, 2008; Garrett, 2010; Harris, 2014; Jones, 2004). The growth of managerialism and the widespread adoption of bureaucratic models of practice have served to dilute the essence of social work as a relationship-based profession (Bamford, 2015; Munro, 2011). And policy rhetoric promising greater choice and control for service users has been used to transfer responsibility for social problems to individual service users (Barnes, 2011; Ferguson, 2007, 2012). These shifts are reflected in social work education. In England there is increasing pressure to prepare students for the workforce by maximising time in practice settings where students are socialized through exposure to statutory interventions reflecting the dominant social control elements of social work (Bamford, 2015). This minimises time available for developing deep, critical understandings of HR and SJ, fundamental concepts for the social work profession (Croisdale-Appleby, 2014; Higgins, 2015). While this situation was articulated most clearly by research participants in England, these market-oriented processes of de-professionalisation 
affecting social work are also found in other European countries including Spain (De la Red and Brezmes, 2009; Ioakimidis, et al., 2014; Ponnert and Svensson, 2016).

The retreat of European welfare states and the expansion of neoliberal models of social work are explained by reference to a combination of causal factors related to global economic forces, politics and ideology (Dominelli and Khan, 2000). European governments, whether conservative or social democratic, have used the pressures of globalization as justification to adopt and reinforce neoliberal policies associated with the retreat of welfare provision and weakening of human rights (Ferguson, 2008). This has left social work in a state of uncertainty and has seen the emergence of a 'neoliberal social work' focussing narrowly on risk management rather than broader notions of empowerment of individuals, families, groups and communities in situations where HR and SJ are threatened or denied. Social work concerns with structural causes of injustice are increasingly interpreted by governments as problematic and as evidence of the need for the reform of social work. The traditional values of social work including respect for persons, belief in individual change, and relationship-based interventions are being continuously eroded as particular social groups such as young people, those seeking asylum or migrating for economic reasons, are demonized in neoliberal societies (Ferguson, 2008). The victimization of vulnerable groups and social work service users were highlighted by all educators interviewed in this study who were unanimous in their views about the importance of helping social work students to understand and overcome prejudices associated with negative images and ideological discourses that serve conveniently to further 'punish the poor' (Wacquant, 2009).

The philosophy, principles and values of the neoliberal market have been argued as being both antithetical to, and irreconcilable with, those of social work, rooted in notions of human dignity, human rights, social justice, universalism, democracy and citizenship (Dominelli, 2010; Eroles, 1997; Ferguson, 2008; Ife, 2008). But there are those in the social 
work scientific community who, however reluctantly, embrace the neoliberal view of the world and engage with the dominant social control role assigned to social work by neoliberal governments since this direction is readily perceived as the sole route to professional and scientific status within the profession (Shaw, 2003). In both England and Spain, controlling features of the profession have been evident through the history of social work although they have co-existed with more enabling practices and radical approaches designed to achieve social change. However, the new millennium, particularly in England, has seen an increasingly rapid tightening of the neoliberal grip and the establishment of a dominant neoliberal paradigm informing social work policy and practice (Higgins, 2015). In these circumstances, the development of effective forms of resistance to neoliberalism and its impact on the social work profession become ever more important, and the process of developing effective resistance requires knowledge and understanding of the contextual factors that can all too easily derail such efforts. It is to these mediating factors that we now turn.

\section{Historico-political, cultural and socio-economic factors mediating responses to neoliberalism}

Consideration of the historical links between the social work profession, western capitalist welfare states and cultural values provides a further opportunity to shed light on the greater historical and contemporary misalignment of mainstream social work with HR and SJ ideals in England compared with Spain. Social work as a profession developed to respond to the economic and social needs of people following the growth of industrialisation in the nineteenth century and rising levels of conflict between the working and ruling classes in western societies (Eroles, 1997). Responsibility for addressing the resulting social problems was first assumed by charitable organisations and gradually extended to nation states which became the main guarantors of social welfare during the twentieth century (Lundy, 2011). 
Thus, the growth of capitalism has been accompanied by state sponsored responses to social problems arising from the predominant economic system. The relationship between capitalism and state welfare has always been complex, highly contradictory, and their coexistence has become increasingly tense and untenable in late-stage or neoliberal global capitalism (Lundy, 2011). As Lundy (2011, p.15) argues, 'addressing societal inequalities and social structures that contribute to such conditions is no longer part of the political agenda'.

In Spain, notwithstanding the influence of international capitalism, the relationship between capitalism, welfare and the nation state has followed a different path given the later development of a welfare state. The dictatorial Franco regime, 1939-1975, left Spain internationally isolated, lacking in democratic and welfare rights. And Spanish social work has been shaped by the process of merging the catholic charity tradition of social welfare provision with the development of a 'scientific' social work profession (Méndez-Bonito, 2005) with limited support from government. Even during the democratic era, social work in Spain has not been subject to significant government control, maintaining autonomy in its education system, its knowledge and value base. The mainly female profession has historically shown strong vocational rather than employment oriented motivation and the profession has maintained greater resistance to market pressures in relation to recruitment (Méndez-Bonito, 2005). As one educator in Spain noted:

There is a high level of commitment [to HR and $\mathrm{SJ}$ ] one has and develops when making the decision to study social work .... I believe that the majority of social work students are very vocational and very eager to change the world. (interview 3 )

By contrast, an educator in England suggested that: 
Students when they graduate they want to find work. They're in a position of 'do you hold on to your moral values or do you take work when you know you need work?' I think there's a real wrestle with those kinds of things. (interview 1)

While Spanish social work and social work education have had briefer exposure to neoliberal ideology Spanish society, strongly influenced by Catholicism and the strength of the family as an institution, is arguably better placed to resist the values of neoliberal capitalism. While both countries have become increasingly culturally diverse and have seen sharp declines in Christian religious adherence, almost $70 \%$ of Spanish citizens continue to describe themselves as Catholic (CIS, 2015), while in 2014, only 43\% of English and Welsh citizens of the UK described themselves as Anglican, Catholic or members of other Christian denominations (Sherwood, 2016).

Acceptance of neoliberal discourses among citizens and social scientists, including social workers, is more likely as societies become increasingly fragmented and plural, less secure and controllable, and where identities, values and lifestyles are reoriented to greater individualism (Dominelli and Khan, 2000). The impact of capitalist economies on individuals, legitimised through the mass media, is well documented (Bourdieu, 2005; Méndez-Fernández et al., 2006) and includes the growth of individualism, consumerism, competitiveness, commodification of personal relationships, weaker social cohesion and cooperation, passivity and hedonism. Those deprived of their rights are persuaded to accept the unified discourse presented by politicians and the media, justifying inequality as the product of personal merit, legitimising the commodification of people, hindering collective action and the defence of human rights (Méndez-Fernández, et al., 2006). Méndez-Bonito (2005) highlights how these traits and values are at odds with traditional Spanish social values that embrace wellbeing as relational, ambivalence towards wealth and prestige, and acceptance of help from family and social, often religious, networks. By contrast, she notes, capitalist values are more easily implanted in societies sensitive to Protestantism such as 
England, where individual notions of success and wellbeing, autonomy and selfdetermination, and a scientific approach to human problems are all held in high regard.

Spanish social work has also been more closely influenced by the radical social work tradition of Latin America sharing some common cultural elements of language and religion, and its own, relatively recent, emergence from the struggle for democratic and welfare rights. This has contributed to the profession's ongoing identity as having a role in promoting structural change and human rights, rejecting narrower neoliberal models of social work education and practice. Open rejection of neoliberalism and austerity measures is evident in the statements and discourses of Spanish social work professional associations (CGTS, 2009; Lima, 2012) and was also evident in survey responses and interviews with social work educators in Spain.

Building on this more nuanced understanding of the differences between the two countries, we turn to explore ways of challenging neoliberalism through the development of an alternative ideology built on HR and SJ, consistent with the international definition of social work.

\section{Challenging neoliberalism through an alternative ideology of human rights and social justice-based social work: Developing "a positive critique".}

This section speaks to Fairclough's (2010) argument that critical social research can contribute to struggles for better societies through a 'positive critique' analysing how capitalism's social wrongs can be mitigated and resisted. Wronka and Staub-Bernasconi (2012) claim that the commitment to human rights articulated in the international definition of social work as a profession and academic discipline (IFSW and IASSW, 2014) provides the profession with autonomy allowing for the refusal of 'illegitimate' demands from social agencies, society and service users. 
Despite working in a context in which narrow neoliberal models of social work practice and education are able to flourish, interview participants in England had found ways of remaining loyal to their professional ideologies and encouraged students to do the same, employing learning and teaching practices described earlier. However, as managerialism and marketization gain further ground in social work education, the space for this type of resistance is likely to be increasingly constrained. In Spain, mainstream social work and social work education remain more strongly aligned with the international definition of social work supporting Carey and Foster's (2011) argument that: occupations such as social work can be seen as capable of producing their own self-determining ideologies that can compete with others.

In this study, the international definition of social work, together with international and national codes of ethics constituted a systematic body of ideas, beliefs and interests capable of producing emancipatory discourses to counter ideological expressions of neoliberalism. The tension between the ideology reflected in international social work ethics and the oppressive ideology of neoliberalism, concerned with maintaining dominant power relations, was evident in social work education in both countries influencing educators' understandings of HR and SJ. The dynamic between these ideologies was mediated by cultural beliefs, norms and values in each country, particularly those informing notions of individualism and communitarianism and the roles and relationships between the individual, family, community, church and state (Tropman, 1985). These contextual features influenced the balance between the positive ideology of international social work ethics, and the oppressive ideology of neoliberalism.

Social work educators, especially in England, continue to face attempts by those who promote, or fail to oppose, the principles of neoliberalism, destabilising the HR and SJ foundations of the profession. The ethical foundations articulated in the international 
definition of social work therefore take on an ever more important role in providing social work practitioners and educators with a legitimate framework from which to pursue the core values of social work and deconstruct neoliberalism. But the potential to realise the aspiration summed up in the expression 'another social work is possible' (Ferguson, 2009) must be accompanied by a dual note of caution. First is Carey and Foster's (2011, p.256) warning that 'self-determining ideologies can adapt, change or even disappear over time'. And second is Foucault's (1990) assertion that while resistance and defiance are natural within discursive terrains, resistance in itself may not necessarily lead to wider change.

\section{Conclusion}

Empirical evidence from this comparative study of social work educators in England and Spain demonstrates the reach of neoliberalism into the realm of social work education where core values of respect for human rights and the pursuit of social justice lie in tension with contemporary policies shaping social work practice. Using a framework of critical realism to 'prise open the black box' (Houston, 2010), this study has sought to offer a more nuanced appreciation of social work educators' understandings of HR and SJ and their application in social work education. The broad comparison between England and Spain has sharpened the focus of understanding by using a process of retroduction, examining patterns in the empirical data in the light of their respective historico-political, cultural and socio-economic contexts. And interviews with educators overtly committed to HR and SJ-based social work have highlighted practices used to facilitate students' appreciation of the importance of HR and SJ in social work nationally and globally that can serve to inspire others in Europe.

However, the persistence of neoliberal agendas shaping social welfare policy and the delivery of public social work services means that social work practitioners and educators alike face continuing uncertainty. Challenging the status quo requires continual critical and creative thinking. Current concerns facing social work in England include political 
aspirations to undermine the power of the Human Rights Act and the climate of xenophobia, legitimized by policies promoting stricter immigration controls for refugees from regimes with little regard for human rights, and for European citizens whose right to free movement is under threat from Brexit. Social work education is also under attack with the introduction of fast track training programmes and apprenticeship schemes that prioritize socialization into practice settings commonly concerned with the social control functions of social work. Government investment in these schemes, together with arrangements that incentivise the development of teaching partnerships between local government social work departments and universities, divert funds away from social work education in higher education institutions further undermining the specialist body of knowledge and value base of the social work profession and limiting the development of critical thinking associated with higher education. In Spain, evidence of a stronger continuing commitment to the interconnected importance of HR and SJ in social work education and practice, with explicit acknowledgement of the relevance of structural causes of social problems, suggest that Spanish social work education is better equipped to resist the influence of neoliberalism. However, in a period marked by the consequences of continuing economic crisis and draconian austerity, and recent developments in political governance that signal the continuing power of right wing politics, the social work profession will require continuing effort to resist and challenge neoliberalism.

The study reported here suggests that the wide range of actors in the social work profession must redouble efforts, nationally and internationally, to seek strategies to counter the social injustices that are the inevitable result of neoliberalism, affecting social work service users, practitioners and educators alike. Further research is required, not only to map developments but to engage service users, practitioners and educators in action research to reclaim and sustain the values of $\mathrm{HR}$ and $\mathrm{SJ}$ in social work education and practice. 


\section{References}

Bamford, T. (2015). A Contemporary History of Social Work. Learning from the past. Bristol: Policy Press.

Banks, S. (2006). Ethics and values in social work (3rd ed.) Basingstoke: Palgrave Macmillan.

Barnes, M. (2011). Abandoning Care? A Critical Perspective on Personalisation from an Ethic of Care. Ethics and Social Welfare, 5(2), pp.153-167.

BASW. (2014). The Code of Ethics for Social Work: Statement of Principles. Retrieved Date 25/10/17 from http://cdn.basw.co.uk/upload/basw_112315-7.pdf.

BASW. (2015). BASW Human Rights Policy Kent: The British Association of Social Workers.

Bhaskar, R. (1979). The possibility of naturalism: a philosophical critique of the contemporary human sciences Brighton: Harvester Press.

Bhaskar, R. (1989). Reclaiming reality: A critical introduction to contemporary philosophy London: Verso.

Blaikie, N., \& Priest, J. (2017). Social Research: Paradigms in Action Cambridge: Polity Press.

Bourdieu, P. (2005). Pensamiento y acción. $2^{a}$ edición. Buenos Aires: Libros del Zorzal.

Bryman A. (2016) Social Research Methods Oxford: Oxford University Press.

Carey, M., \& Foster, V. (2011). Social work, ideology, discourse and the limits of posthegemony. Journal of Social Work, 13(3), pp.248-266.

CGTS. (2009). Manifiesto Trabajo social ante la Crisis: Consejo General del Trabajo Social.

CGTS. (2012). Codigo deontologico del Trabajo Social. Retrieved Date 25/10/17 from https://www.cgtrabajosocial.es/consejo/codigo_deontologico.

CIS. (2015). 3050| Barómetro de Enero 2015.

Croisdale-Appleby, D. (2014). Re-visioning social work education. An independent review. London: Department of Health.

Danermark, B., Ekström, M., Jakobsen, L., \& Karlsson, J. C. (2002). Explaining society. Critical realism in the social sciences London: Routledge.

De la Red, N., \& Brezmes, M. (2009). Trabajo Social en España. In T. Fernández García \& C. Alemán-Bracho (Eds.), Introducción al trabajo social (pp.131-152). Madrid: Alianza.

De Vogli, R. (2013). Financial crisis, austerity, and health in Europe. The Lancet, 382(9890), p 391. doi:https://doi.org/10.1016/S0140-6736(13)61662-1 Retrieved from http://www.sciencedirect.com/science/article/pii/S0140673613616621

Dominelli, L. (2004). Social work : theory and practice for a changing profession Oxford: Polity.

Dominelli, L. (2010). Social work in a globalizing world Cambridge: Polity Press.

Dominelli, L. (2012). Green social work : from environmental crises to environmental justice Cambridge: Polity.

Dominelli, L., \& Khan, P.(2000). The impact of globalization on social work in the UK. European Journal of Social Work, 3(2), pp.95-108.

Dustin, D. (2007). The McDonaldization of social work Aldershot: Ashgate.

Eroles, C. (1997). Derechos humanos: compromiso ético del trabajo social. In C. Eroles, N. Fóscolo \& M. C. G. d. Camín (Eds.), Los Derechos Humanos: Compromiso ético del Trabajo Social. Buenos Aires: Espacio Editorial.

Eurostat. (2013). People at risk of poverty or social exclusion by age and sex. Retrieved Date 30/9/16 from http://appsso.eurostat.ec.europa.eu/nui/show.do?dataset=ilc_peps01\&lang=en. 
Fairclough N. (2003) Analysing discourse: textual analysis for social research, London: Routledge.

Fairclough, N. (2010). Critical discourse analysis : the critical study of language (2nd ed.) Harlow: Longman.

Ferguson, I. (2007). Increasing User Choice or Privatizing Risk? The Antinomies of Personalization. The British Journal of Social Work, 37(3), pp.387-403.

Ferguson, I. (2008). Reclaiming social work: Challenging neo-liberalism and promoting social justice London: Sage.

Ferguson, I. (2009). 'Another Social Work is Possible!' Reclaiming the Radical Tradition. In V. Leskošek (Ed.), Theories and Methods of Social Work: Exploring Different Perspectives (pp.81-98): University of Ljubljana, Faculty of Social Work.

Ferguson, I. (2012). Personalisation, social justice and social work: a reply to Simon Duffy. Journal of Social Work Practice, 26(1), pp.55-73.

FOESSA. (2013). Desigualdad y Derechos Sociales. Análisis y Perspectivas 2013 Madrid: Foessa; Cáritas.

Foucault, M. (1990). The archeology of knowledge London: Routeledge.

Garrett, P.M. (2010). Examining the 'Conservative Revolution': Neoliberalism and Social Work Education. Social Work Education, 29(4), pp.340-355.

Hall, S. (1977). The hinterland of science: Ideology and the 'sociology of knowledge'. In C. f. C. C. Studies (Ed.), On ideology (pp.6-15). London: Hutchinson.

Harris, J. (2014). (Against) Neoliberal social work. Critical and Radical Social Work, 2(1), pp.7-22.

Harvey, D. (2005). A Brief History of Neoliberalism Oxford University Press.

Higgins, M. (2015). The struggle for the soul of social work in England. Social Work Education, 34(1), pp.4-16.

Houston, S. (2010). Prising Open the Black Box:Critical Realism, Action Research and Social Work. Qualitative Social Work, 9(1), pp.73-91.

Ife, J. (2008). Human Rights and Social Work: Towards rights-based practice New York: Cambridge University Press.

IFSW, \& IASSW. (2014). Global Definition of Social Work. Retrieved Date 30/10/17 from http://ifsw.org/get-involved/global-definition-of-social-work/.

Ioakimidis, V., Cruz-Santos, C., \& Martínez-Herrero, I. (2014). Reconceptualizing social work in times of crisis: An examination of the cases of Greece, Spain and Portugal. International Social Work, 57(4), pp.285-300.

Jones, C. (2004). The Neo-Liberal Assault: Voices from the Front Line of British State Social Work In I. Ferguson, M. Lavalette \& B. Whitmore (Eds.), Globalisation, Global Justice and Social Work (pp.97-108). London: Taylor and Francis.

Jordan, B., \& Drakeford, M. (2012). Social work and social policy under austerity New York: Palgrave Macmillan.

Lavalette, M. (Ed.). (2011). Radical social work today. Social work at the crossroads. Bristol: Policy Press.

Lima, A.I. (2012). Alliance for the Defence of Social Services: Spanish Network in Defence of Social Rights and a Public System of Social Services. In N. Hall (Ed.), Social Work Around the World V: Building the Global Agenda for Social Work: IFSW.

Lundy, C. (2011). Social Work, Social Justice, and Human Rights: A Structural Approach to Practice Toronto Univ Press.

McEvoy, P., \& Richards, D. (2006). A critical realist rationale for using a combination of quantitative and qualitative methods. Journal of Research in Nursing, 11(1), pp.6678. 
Méndez-Bonito, P.(2005). The history of social work education in Spain: Does harmonisation make sense? Portularia, 5(1), pp.205-222.

Méndez-Fernández, A.B., Leal-Freire, B., Martínez-Rodríguez, M., \& Salazar-Bernanrd, J. I. (2006). Aprehendiendo a respetar: La perspectiva de Derechos Humanos como elemento fundamental en la formación y práctica del trabajo social. Acciones e Investigaciones sociales, 1 , pp.460-487.

Munro, E. (2011). The Munro review of child protection: Final report, a child-centred system: The Stationery Office.

Murray, C.R.G. (2017). Magna Carta's Tainted Legacy: Historic Justifications for a British Bill of Rights and the Case Against the Human Rights Act. In F. Cowell (Ed.), The Case Against the 1998 Human Rights Act: A Critical Assessment: Routledge.

Piketty, T. (2014). Capital in the twenty-first century: Cambridge Massachusetts: Harvard University Press.

Ponnert, L., \& Svensson, K. (2016). Standardisation - the end of professional discretion? European Journal of Social Work, 19(3-4), pp.586-599.

Sewpaul, V., \& Jones, D. (2005). Global standards for the education and training of the social work profession. International Journal of Social Welfare, 14(3), pp.218-230.

Shaw, I. (2003). Critical Commentary. Cutting Edge Issues in Social Work Research. British Journal of Social Work, 33, pp.107-116.

Sherwood, H. (2016). People of no religion outnumber Christians in England and Walesstudy. The Guardian. Retrieved from https://www.theguardian.com/world/2016/may/23/no-religion-outnumber-christiansengland-wales-study.

Soydan, H. (2010). Politics and Values in Social Work Research. In I. Shaw, K. BriarLawson, J. Orme \& R. Ruckdeschel (Eds.), The SAGE Handbook of Social Work Research (pp.131-148). London: Sage.

The Equality Trust. (2017). How Has Inequality Changed?. Development of UK Income Inequality. Retrieved Date 20/6/17 from https://www.equalitytrust.org.uk/how-hasinequality-changed.

Tropman, J.E. (1985) The "catholic ethic" vs the "protestant ethic": Catholic social service and the welfare state. Social Thought 12: 13-22.

Wacquant, L. (2009). Punishing the poor: The neoliberal government of social insecurity Durham: Duke University Press.

Wronka, J., \& Staub-Bernasconi, S. (2012). Human Rights. In K. Lyons, T. Hokenstad, M. Pawar, N. Huegler \& N. Hall (Eds.), The SAGE Handbook of International Social Work (pp.70-84). London: SAGE. 